\title{
Invited review: Influence of climatic conditions on the development, performance, and health of calves
}

\author{
L. Roland, M. Drillich, D. Klein-Jöbstl, and M. Iwersen ${ }^{1}$ \\ Clinical Unit for Herd Health Management in Ruminants, University Clinic for Ruminants, Department for Farm Animals \\ and Veterinary Public Health, University of Veterinary Medicine Vienna, 1210 Vienna, Austria
}

\begin{abstract}
The objective of this review is to provide the reader with an overview of thermoregulatory mechanisms and the influence of climatic conditions in different housing systems on the development, performance, and health of calves. Thermic stress is observed in association with extreme temperatures and large temperature variations, but other variables such as relative humidity and wind speed can also contribute to thermic stress. Thermoregulation in calves is similar to that in adult cattle, but especially dystocial calves are more prone to heat loss. Heat or cold stress results in direct economic losses because of increased calf mortality and morbidity, as well as indirect costs caused by reduced weight gain, performance, and long-term survival. The climatic conditions in a variety of housing systems, associated health problems, and strategies to mitigate thermic stress are discussed in this review. The goal of housing is to alleviate the effect of climate on calves and provide a microclimate. Adequate ventilation with fresh air is essential to reduce respiratory disease. Common practices such as raising calves in individual outdoor enclosures have been challenged lately. Recent research seeks to evaluate the suitability of group housing under practical, economic, and animal welfare considerations. Limited results for reducing thermic stress can be achieved by simple measures such as shades or shelter, but additional heat or cold stress relieving strategies can be required depending on the housing system.
\end{abstract}

Key words: calf, climate, thermoregulation, heat stress, cold stress

\section{INTRODUCTION}

Thermoregulation is the ability of homeothermic animals to keep their body temperature within a certain range despite being exposed to different ambient temperatures (Bligh, 1998). A physiological core tem-

Received June 2, 2015.

Accepted December 28, 2015.

${ }^{1}$ Corresponding author: michael.iwersen@vetmeduni.ac.at perature is maintained by generating metabolic heat as well as exchanging heat with the environment (Da Silva, 2012).

Animals are able to adjust to adverse climate by means of acclimatization and adaptation (Roy and Collier, 2012). Extreme climatic conditions that cannot be compensated by thermoregulatory mechanisms result in thermic stress. Thermic stress in calves has a negative effect on animal welfare (Silanikove, 2000) and causes direct economic losses in the form of mortality and morbidity, and indirect costs caused by reduced weight gain, performance, and long-term survival (Virtala et al., 1996; Donovan et al., 1998; Snowder et al., 2006). Because some subspecies and breeds are better adapted to a hot climate (Cartwright, 1955; Silva et al., 2013), efforts have been made to create heat-resistant and high-performing crossbreeds, but with varying results (McDowell, 1985; Rutledge, 2001; Eberhardt et al., 2009).

Different housing systems have been developed to protect calves from extreme climatic conditions and thermic stress. Depending on the climate, culture, and intended use of animals (e.g., beef versus dairy) these include open range, shelters, pens, or hutches, and naturally or mechanically ventilated stables (Seedorf et al., 1998; Moran, 2002; Marcé et al., 2010). Whereas some housing systems principally succeed in providing thermal comfort to calves, other problems, such as poor air quality, might arise from their use. Ongoing research aims to identify the best housing system for a particular climate.

Diarrhea and respiratory disease, the 2 most common health problems when raising calves, are typically caused by multiple factors, with climate and housing system playing an important role in the etiology (Roy, 1980; Barrington et al., 2002; Gorden and Plummer, 2010; Walker et al., 2012). The incidence of respiratory diseases tends to be higher in calves reared in mechanically ventilated barns than in calves housed with natural ventilation or in outdoor enclosures (Okamoto et al., 1993; Wójcik et al., 2012; Table 1).

Many publications cover specific aspects of thermoregulation, thermic stress, effect of climatic conditions 
INVITED REVIEW: INFLUENCE OF CLIMATE ON CALVES

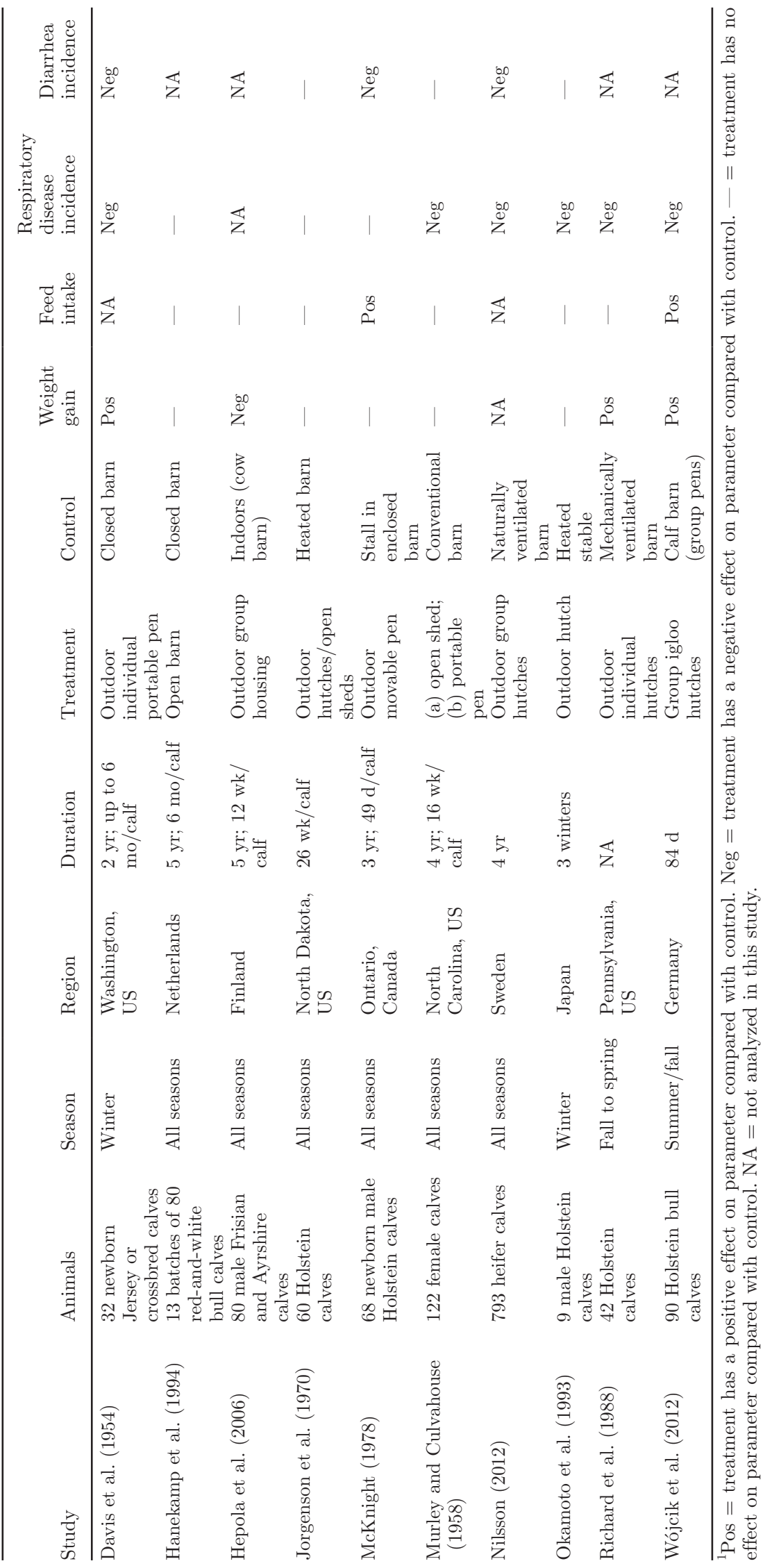


and housing conditions, as well as husbandry-associated diseases in calves. Although several reviews have been published on the effect of climate and thermic stress on cattle and dairy cows, to our knowledge this is the first comprehensive review covering the influence of climatic conditions and housing system on the performance and health status with a focus on calves.

\section{THERMOREGULATION}

Homeothermic animals keep their body temperature almost constant. They generate metabolic heat and continuously exchange heat with the environment. The rate of heat exchange depends on the climatic environment and the thermoregulation mechanisms of an animal. Thermoregulation involves physiological, morphological, and behavioral mechanisms (Khalifa, 2003; Ivanov, 2006; Da Silva, 2012). The heat balance of an animal is composed of the heat produced by metabolic and muscular activity as well as heat exchanges with the environment (IUPS, 2001). The mechanisms of heat transfer (convection, conduction, thermal radiation, and evaporation) are well known and explained, for example, by Turnpenny et al. (2000) and Spiers (2012).

Calves are born with functional thermoregulatory mechanisms (Gluckman et al., 1999; Schäffer and von Borrell, 2008). Approximately $2 \%$ of their BW is composed of brown adipose tissue, which is involved in nonshivering thermogenesis (Alexander et al., 1975; Morrison, 2004). Intake of colostrum also contributes to heat generation (Vermorel et al., 1989b). Newborn calves, however, are prone to heat loss under cold conditions because of their low surface/mass-ratio and poor insulation [i.e., thin skin and subcutaneous fat (Gonzalez-Jimenez and Blaxter, 1962; Olson et al., 1980a; Berman, 2003; Van Iaer et al., 2014)]. Further, they cannot rely on heat production by ruminal fermentation (Collier et al., 1982). Healthy calves are physically active, which increases heat production and cold resistance (Vermorel et al., 1989b). They are remarkably tolerant toward sustained cold if hair coat and bedding are dry, the lying area is protected from drafts, and sufficient nutritional energy is provided (Rawson et al., 1989b; Schäffer and von Borrell, 2008; Nonnecke et al., 2009). In dystocial calves, heat generation mechanisms are often impaired. Inhibited vasoconstriction and muscle shivering, and reduced activity result in a lower tolerance toward cold. Thermogenesis in dystocial calves is up to $36 \%$ lower than in eutocial calves (Vermorel et al., 1989a). Thus, diseased or weak calves should be housed in a warm and dry environment (Martin et al., 1975). Under cold conditions, infrared lamps can be used to provide a warm microclimate. Borderas et al. (2009) installed infrared heat lamps in calf pens in a naturally ventilated barn during winter and studied the temperature preferences of newborn dairy calves. The calves spent more time under the heat lamps than in other pen areas. The heat lamps were sought after by the older calves more often, indicating a better ability to thermoregulate by actively choosing warm places with increasing age.

Body temperature and heat production of mammals typically follow a circadian rhythm and vary with activity, resulting in changing thermal requirements during the day (Berman and Zamsky, 1971; Schrama et al., 1994). In newborn calves, the rhythmicity of body temperature is absent during the first week after birth, but develops and stabilizes during the first 2 mo of life (Piccione et al., 2003). The physiological range of the rectal temperature of calves is 38.1 to $39.2^{\circ} \mathrm{C}$ (Moran, 2002; Piccione et al., 2003). In an Italian study, the mean rectal temperature of calves with an established temperature rhythm exposed to natural summer temperatures $\left(22\right.$ to $\left.28^{\circ} \mathrm{C}\right)$ was $38.3^{\circ} \mathrm{C}$, with diurnal variations of $1.4^{\circ} \mathrm{C}$. In 2 -mo-old calves, body temperature increased during the day, peaked in the evening, and decreased during the night (Piccione et al., 2003). Rectal temperature was shown to increase with a high ambient temperature and decrease with high relative humidity and wind velocity. This should be taken into consideration when using it as a diagnostic tool (Theurer et al., 2014).

Little information is available with regard to differences in thermoregulation under hot conditions between calves and adult cattle. Klemm and Robinson (1955) showed that evaporating heat loss increased with age from 1 to 8 mo in Australian Illawara Shorthorn calves. Broucek et al. (2009) evaluated the effect of hot temperatures on performance and on the hemogram of Holstein calves and concluded that the calves were able to maintain homeostasis under prolonged heat stress.

The existing knowledge of many basic principles of thermoregulation is often based on experiments with other species. More studies are warranted to confirm that the results are fully applicable to bovines under current management conditions. Studies concerning the thermoregulation of the bovine fetus are also limited.

Some studies dealing with thermoregulation or thermal stress (Klemm and Robinson, 1955; Berman and Zamsky, 1971; Christison and Johnson, 1972; King et al., 2006; Bertagnon et al., 2011) are based on a small number of animals. Other studies cover a specific climatic region only (Ehrenreich and Bjugstad, 1966; Frank and Kaneene, 1993; Donovan et al., 1998; Svensson et al., 2003; Broucek et al., 2008; Gulliksen et al., $2009 \mathrm{~b}$ ) or are based on observations from a single herd, farm, or research station (Hoshiba, 1986; Diesch et al., 2004a,b; Wójcik et al., 2012). 


\section{Thermoneutral Zone and Critical Temperatures}

The thermoneutral zone (TNZ) is the range of ambient temperatures in which the heat production of an individual is independent from the environmental temperature (Webster, 1974; Spiers, 2012). The TNZ is comfortable for the animal, the core temperature is generally within physiological limits, and body temperature regulation is achieved only by sensible heat loss (Charles, 1994; IUPS, 2001). Some researchers divide the TNZ into subzones [e.g., the zone of thermal wellbeing and zones in which moderate activation of thermoregulatory mechanisms occurs (Silanikove, 2000)]. If the ambient temperature falls below the lower critical temperature $\left(\mathbf{T}_{\mathrm{lc}}\right)$, the rate of metabolic heat production increases to maintain thermal balance. If the ambient temperature exceeds the upper critical temperature $\left(\mathbf{T}_{\mathbf{u c}}\right)$, heat is dissipated via sensible heat loss and evaporation (IUPS, 2001). If the thermal strain on the animal is too high and body temperature continues to rise (or fall) despite activation of all possible thermoregulatory mechanisms, hyperthermia (or hypothermia) occurs (Silanikove, 2000). For most mammals, a core temperature exceeding $45^{\circ} \mathrm{C}$ is fatal, resulting in brain damage. A core temperature of below $27^{\circ} \mathrm{C}$ can cause lethal cardiac fibrillation (Robinson, 2013). Robinson and Young (1988) demonstrated that calves can recover from a rectal temperature as low as $30^{\circ} \mathrm{C}$.

The TNZ depends on various physiological and environmental factors [e.g., age, size, breed, nutrition, hair coat, behavior, bedding, and weather (Webster, 1974; Holmes et al., 1978; Schrama et al., 1993b)]. Thus, a variety of TNZ for calves can be found in the literature, ranging from 0 to $26^{\circ} \mathrm{C}$ (Wathes et al., 1983; Nonnecke et al., 2009). Reported $\mathrm{T}_{\text {lc }}$ values range from 0 to $18^{\circ} \mathrm{C}$, depending on the age of the calves. Wet and windy weather conditions result in an increase of $\mathrm{T}_{\mathrm{lc}}$ (Gonzalez-Jimenez and Blaxter, 1962; Webster et al., 1970; Webster, 1974; Schrama et al., 1993a,b). With regard to $T_{u c}$, less information is available. Spain and Spiers (1996) indicated a $\mathrm{T}_{\mathrm{uc}}$ of $26^{\circ} \mathrm{C}$, above which calves exhibit an increased respiratory rate.

\section{Role of the Nervous System in Thermoregulation}

Thermoreceptors are sensory neurons (type $\mathrm{A} \delta$ or C) in the skin, brain, and viscera that respond to heat or cold (Nagashima et al., 2000; Schepers and Ringkamp, 2010). Different types of temperature-activated transient receptor potential ion channels have been identified in cutaneous sensory neurons and skin cells, and seem to respond to different temperature ranges (Bandell et al., 2007; Lumpkin and Caterina, 2007;
Schepers and Ringkamp, 2010). The traditional school of thought states that afferent signals are passed via the spinal dorsal horn and the lateral parabrachial nucleus to the preoptic region of the hypothalamus, where they are compared with the thermal status of the hypothalamus itself (Morrison and Nakamura, 2011; Robinson, 2013). If a deviation is detected, effectors (such as vasculatory muscle cells, skeletal muscle cells, or brown adipocytes) are activated by parallel effector-specific core-efferent pathways. This results either in producing or dissipating heat, for example by vasoconstriction or vasodilation, muscle shivering, or the activation of brown adipose tissue (Nagashima et al., 2000; Morrison, 2004; Morrison and Nakamura, 2011; Robinson, 2013). Another ascending route is the spinothalamocortical pathway, which mediates conscious thermal reception (Craig et al., 1994). A detailed review of neural pathways for thermoregulation is provided by Morrison and Nakamura (2011) and Nagashima et al. (2000). The theory of a comparison of input from thermoreceptors with a single central set point temperature has been challenged lately. The function of peripheral receptors as "comparators" without the transmission of signals to the brain and the presence of independent thermoeffector loops for body temperature regulation have been proposed instead (Kobayashi et al., 2006; Romanovsky, 2007; Werner, 2010). More research is necessary to fully understand the neural pathways of thermoregulation.

\section{Role of the Endocrine System in Thermoregulation}

Hormones involved in thermoregulation include predominantly glucocorticosteroids, thyroid hormones, and catecholamines. Glucocorticosteroids, mainly cortisol, are released via the hypothalamic-pituitary-adrenal axis in response to acute (thermal) stress, which results in increased blood glucose availability (Olson et al., 1981; Collier et al., 2006). The concentration of plasma cortisol in calves is typically high at birth and decreases during the first week of life (Hadorn et al., 1997; Hammon and Blum, 1998). It remains high in case of feed deprivation and decreases after feed intake (Lee et al., 1995; Hammon and Blum, 1998). Plasma cortisol levels sharply increase $20 \mathrm{~min}$ after the beginning of acute moderate thermal stress, and reach a plateau after 2 to $4 \mathrm{~h}$. With chronic, mild heat stress, cortisol levels return to normal after 1 to $2 \mathrm{~d}$, and become depressed with continuous onset of heat stress over several weeks (Christison and Johnson, 1972).

The plasma concentration of triiodothyronine (T3) and thyroxin (T4) was shown to be high in newborn calves and declined during the first week of life (Ha- 
dorn et al., 1997; Egli and Blum, 1998). Grongnet et al. (1985) observed that the T4 profile depended on the diet of calves, whereas other researchers were not able to confirm this observation (Hammon and Blum, 1998). The plasma levels of T3 and T4 decline under warm conditions and increase under cold conditions. They respond slower to external stimuli than glucocorticosteroids (Young, 1981; Khalifa, 2003).

The plasma concentration of the catecholamines epinephrine and norepinephrine is elevated during the perinatal period (Richet et al., 1985; Hammon et al., 2012). Catecholamines are released during acute thermal stress and act together with an increased sympathetic activity (Olson et al., 1981; Young, 1981). An increased level of antidiuretic hormone has been found during heat stress, which is linked to the need to conserve water (Beede and Collier, 1986). Further hormones involved in temperature-related metabolic changes include somatotropin, IGF-I, insulin, and prolactin (Roy and Collier, 2012).

\section{Acclimatization, Acclimation, and Adaptation}

Acclimatization describes the change in phenotype by which individuals adjust to exposure to several environmental stressors. Acclimation refers to a single stressor. Adaptation describes the permanent change in the genotype of a population in response to environmental conditions (Roy and Collier, 2012).

Acclimatization includes endocrine, cellular, and metabolic responses. Examples for seasonal acclimatization include hair coat thickness, fat deposition, or increased feed intake (Roy and Collier, 2012). With climatic stress, acclimatization takes days or weeks and is fully achieved when the body temperature returns to the prestress level (Nienaber et al., 1999). On the endocrine level, a decrease in thyroid hormone levels occurs in response to heat acclimatization (Silanikove, 2000). Metabolic rate and heat production increase with cold climate and decrease with warm climate (Young, 1981; Brown-Brandl et al., 2003). Water and electrolyte metabolism, however, is accelerated with chronic heat stress (Beede and Collier, 1986).

A short-term and a long-term phase of acclimatization can be distinguished. Short-term acclimatization involves behavioral mechanisms, activation of the nervous and endocrine system, and changes in cellular signaling pathways. During long-term acclimatization, a change in gene expression takes place and the effect of the stressors on the animal is reduced (Collier et al., 2006; Roy and Collier, 2012). Hahn et al. (1990) observed that cattle cope with heat via behavioral mechanisms (e.g., reduction of feed intake), followed by physiological mechanisms after 2 to $4 \mathrm{~d}$ of exposure. Brown-Brandl et al. (2003) studied acclimatization in feeder cattle and found that a metabolic shift occurred between acute and chronic heat stress. The respiration quotient (liters of carbon dioxide produced divided by liters of oxygen consumed) increased and heat production decreased with acclimatization to heat stress. Sudden heat waves affected nonacclimatized animals more severely (Brown-Brandl et al., 2005). Critical temperatures and the TNZ change during acclimatization. Animals kept permanently under cold climatic conditions exhibited an increased basal metabolic rate and a reduced upper and lower critical temperature (Webster et al., 1970; Young, 1983; Robinson et al., 1986). Acquired heat tolerance might be linked to increased levels of heat shock protein (Kregel, 2002).

Certain subspecies and breeds are better adapted to certain climatic conditions than others; for example, Bos indicus (Zebu) cattle are better adapted to tropical climates, whereas Bos taurus cattle are better adapted to temperate climates (Finch, 1986; Eberhardt et al., 2009; Silva et al., 2013). Factors that likely contribute to the higher heat tolerance of Zebu breeds include a lower metabolic rate, lower resistance in the heat transfer from tissues to skin, different sweating patterns, more arteriovenous anastomoses, and different coat types (Finch, 1986; Roy and Collier, 2012). Thus, it can be more profitable and sustainable to use indigenous breeds or crossbreds in tropical regions (Cartwright, 1955; King et al., 2006). On the other hand, Brahman calves have more difficulties adapting to cold environments compared with crossbred calves. In a study by Godfrey et al. (1991), Brahman calves had lower rectal temperatures and were less able than crossbreds to use energy-containing blood constituents (glucose, triglyceride, nonesterified fatty acids, and so on) to increase their body temperature when exposed to a cold environment $\left(4^{\circ} \mathrm{C}\right)$.

For a long time, efforts have been made to produce a heat-tolerant yet high-producing breed by crossbreeding dairy breeds and tropical breeds. First-generation offspring $\left(F_{1}\right)$ sired by dairy breeds tend to perform better than other crosses or indigenous cattle under extensive conditions (McDowell, 1985; McDowell et al., 1996; Rutledge, 2001). Klemm and Robinson (1955) demonstrated that young Zebu-Hereford crosses exhibited a higher heat tolerance due to a superior sweating mechanism and decreased heat production compared with Jersey or Illawarra Shorthorn calves. Other crosses besides the $F_{1}$ have not succeeded so far because favorable epistatic combinations tend to be lost during recombination at meiosis (Syrstad, 1989; Rutledge, 2001). 


\section{THERMIC STRESS}

Thermic stress can be defined as a change in the thermal environment, which causes a change in body temperature that is not compensated by thermoregulatory mechanisms. The deviation of the body temperature and activation of thermoregulatory effector organs caused by thermic stress is defined as thermic strain (IUPS, 2001). Both terms are often used interchangeably (Spiers, 2012). Uncompensated thermic strain on calves can lead to hyper- or hypothermia, and in extreme cases to heat stroke, frostbite injuries, or death (Martin et al., 1975; Olson et al., 1980a; Cruz and Naylor, 1993). Although temperature is the most widely used measure to assess thermal stress, other parameters can influence the perception of warmth or cold of an individual. For example, high humidity or solar radiation amplifies the effect of high temperatures, whereas high wind velocity or precipitation increases the perception of low temperatures (Da Silva, 2012). Precipitation has a negative effect on calf survival, especially when combined with low temperatures (Azzam et al., 1993; Stull et al., 2008). Climatic measurements to evaluate thermic stress should ideally be taken directly on the farm as these measurements often deviate from official meteorological data (Schüller et al., 2013).

\section{Cold Stress and Heat Generation}

Thermoregulatory responses for heat generation include shivering and nonshivering thermogenesis. Nonshivering heat production mechanisms include an increase of the metabolic rate, piloerection, and vasoconstriction (Robinson and Young, 1988; Rawson et al., 1989a; Ivanov, 2006; Kirch et al., 2008). Piloerection results in an almost doubled depth of the hair coat (Gonzalez-Jimenez and Blaxter, 1962). Newborn calves also generate heat by the oxidation of brown adipose tissue (Alexander et al., 1975; Young, 1981). Behavioral responses to cold ambient temperatures include seeking shelter, increased locomotion, posture, and crowding or huddling (Khalifa, 2003; Da Silva, 2012; Spiers, 2012).

After birth, calves exhibit an initial decrease in body temperature caused by evaporation from the wet hair coat, followed by an increase in body temperature after the coat has dried (Vermorel et al., 1989b; Diesch et al., 2004a). Diesch et al. (2004a,b) studied the physiological status of newborn dairy calves in New Zealand and found that calves born during cold $\left(<10^{\circ} \mathrm{C}\right)$, wet, and windy weather conditions had lower rectal temperatures and took a longer time to stand up than calves born during warm and dry weather. Rawson et al. (1989b) observed that cold housing conditions (-8 to $-30^{\circ} \mathrm{C}$ ) were associated with lower rectal tempera- tures and respiratory rates and higher heart rates in calves. The metabolic rate of calves exposed to cold was increased, particularly during standing. Scibilia et al. (1987) recorded lower daily weight gains, water intake, rectal temperature, and respiratory rate as well as a $32 \%$ increase in maintenance energy requirement for calves raised at $-4^{\circ} \mathrm{C}$, compared with calves housed at $10^{\circ} \mathrm{C}$. In experimentally cold-stressed newborn calves, overall depression, muscle shivering, and relaxation as well as delayed absorption of colostral immunoglobulins were observed (Olson et al., 1980a,b). Robinson and Young (1988) induced hypothermia (rectal temperature of $30^{\circ} \mathrm{C}$ ) in calves by water immersion and evaluated different recovery methods. Peak metabolism during the cooling procedure occurred on average at a rectal temperature of $36^{\circ} \mathrm{C}$. Regaining euthermia by placing calves in a warm water bath $\left(38^{\circ} \mathrm{C}\right)$ was faster and more efficient than by placing them in a warm box (20 to $25^{\circ} \mathrm{C}$ ) with blankets or infrared heat lamps (Robinson and Young, 1988).

Cold stress leads to increased feed intake, with a higher amount of feed energy directed toward heat production. There is evidence that the digestive function is suppressed under cold stress. In extreme cold, increased DMI cannot match increased heat production, resulting in a drop in performance. Restrictive feeding has a negative effect on cold tolerance, particularly in young calves, whose body fat reserves become depleted quickly (Young, 1981; Scibilia et al., 1987; NRC, 2001). A limited feeding regimen under cold conditions results in a decreased protein synthesis, especially in skin and muscle cells (Scott et al., 1993). Schingoethe et al. (1986) and the NRC (2001) recommended increasing the quantity of liquid diet or the amount of solids (at least $0.56 \mathrm{~kg} / \mathrm{d}$ ) in the liquid diet of calves during cold weather and providing warm water 2 to 3 times per day to stimulate starter intake. Ad libitum feeding strategies account for these demands. The supplementation of fat in the liquid diet during cold stress increases BW gain during the preweaning period but decreases starter intake and can result in a suboptimal ratio of $\mathrm{CP}$ to $\mathrm{ME}$ (Jaster et al., 1990; Litherland et al., 2014). Nonnecke et al. (2009) compared the performance of preruminant calves in a warm (average temperature $15^{\circ} \mathrm{C}$, average relative humidity $59 \%$ ) and a cold (average temperature $5^{\circ} \mathrm{C}$, average relative humidity $68 \%$ ) environment. The calves and their surroundings in the cold environment were wetted to augment humidity and cold perception. Calves raised in the cold environment exhibited similar weight gains compared with the calves raised in the warm environment, but consumed more concentrates. Okamoto et al. (1993) observed a higher intake of milk replacer by calves raised in simple outdoor housing systems during winter than calves raised indoors. 
Calves spend a large amount of time lying down, which conserves heat and decreases critical temperature. A greater heat production is observed in standing versus lying calves; however, it is usually overcompensated by an increased convective and conductive heat loss (Schrama et al., 1993a; Borderas et al., 2009).

Insulation is provided by the subcutaneous adipose tissue, the skin, the hair coat, and the surrounding air layer (McLean, 1963; Rawson et al., 1989a). Cattle that are kept under cold conditions develop a denser hair coat due to reduced hair shedding than cattle kept in warm temperatures (Webster et al., 1970; Krastev, 2002). A higher amount of thermal radiation is absorbed by animals with dark hair coats than with light-colored hair coats (Mader et al., 2002).

Pathologic cold lesions include subcutaneous edema and hemorrhage as well as intraarticular hemorrhage and synovitis, especially at the limbs (Olson et al., 1980a; Rawson et al., 1989b). In very cold regions, frostbite injuries are observed under field conditions. They are often accompanied by other diseases (Cruz and Naylor, 1993). Gulliksen et al. (2009b) observed that calves born during the winter in Norwegian dairy herds were more likely to die during their first week of life than calves born during the summer.

Cold stress is associated with alterations in hematological and biochemical parameters. Higher total protein, albumin (Scibilia et al., 1987), erythrocyte counts, hemoglobin, and hematocrit (Krastev, 2002) have been found in calves kept in a cold environment. Tzou et al. (1991) identified cold-stressed calves based on changes in bilirubin. Serum phosphate (Krastev, 2002), sodium, and potassium (Coban and Sabuncuoglu, 2005) were decreased under cold conditions in some studies. The effect of cold stress on electrolyte status, however, is controversial, and the results are probably influenced by other factors besides temperature. Plasma glucose concentration decreases under cold husbandry conditions (Scibilia et al., 1987; Nonnecke et al., 2009), but increases in response to sudden cold stress (Olson et al., 1981). Nonnecke et al. (2009) reported an increased concentration of nonesterified fatty acids in calves housed in a cold environment. In contrast, Rawson et al. (1989b) did not find any substantial hematological or biochemical changes in cold-stressed calves.

\section{Heat Stress and Heat Dissipation}

Whereas heat stress is a constant concern in subtropical or tropical countries, even in temperate regions summer temperatures frequently exceed the TNZ in cattle (Van Iaer et al., 2014). Neuwirth et al. (1979) observed heat stress in calves with an ambient temperature above $32^{\circ} \mathrm{C}$ and a relative humidity above
60\%. Spain and Spiers (1996) observed an increase in the respiration rate in calves at $26^{\circ} \mathrm{C}$. At a rectal temperature beyond $40.5^{\circ} \mathrm{C}$, minute volumes increased as well, causing a respiratory acidosis (Findlay, 1957). Brown-Brandl et al. (2003) emphasized the diurnal pattern of respiration rate and rectal temperature, which followed ambient temperature with a time lag of 1.5 to $2 \mathrm{~h}$ and 4 to $5 \mathrm{~h}$, respectively. Theurer et al. (2014) evaluated the effect of weather variables on thermoregulation of calves during heat stress. They found a positive relationship between ambient temperature and temperature humidity index and the rectal and nasal submucosal temperature. High relative humidity, wind speed, and barometric pressure resulted in a decrease of rectal and nasal submucosal temperature. Under heat stress, nasal submucosal temperature can exceed $39^{\circ} \mathrm{C}$, which might result in an inactivation of temperaturesensitive intranasal vaccines (Theurer et al., 2014).

Behavioral modifications observed during heat stress include seeking shade, changing posture (standing vs. lying), body alignment away from the sun, reducing locomotion during hot times of the day, and bunching to seek shade from other animals (Schrama et al., 1993a; Gaughan et al., 2002; West, 2003). With high ambient temperature, feed intake, grazing time, and weight gain decline, whereas water intake rises (Ehrenreich and Bjugstad, 1966; Broucek et al., 2008). Brosh et al. (1998), Mader et al. (2002), and Mader (2003) observed that heat production in cattle increased after feeding and recommended limiting the amount of feed during hot times of the day. The decline in DMI caused a reduction in metabolic heat generated by digestion, thus helping to maintain thermal balance. Whereas digestibility is slightly enhanced due to a longer retention time of ingesta in the gastrointestinal tract, nutrient absorption is reduced due to a decreased blood flow to the intestines. This results in a reduced intake of nutrients under heat stress (Beede and Collier, 1986). The composition of nutrient requirements may also change because of heat stress. Cattle sweat is high in potassium and urinary excretion of sodium is higher than normal under heat stress, meaning potassium and sodium needs might be increased. Furthermore, vitamin A can be required in higher levels (Beede and Collier, 1986). Further research is needed to evaluate the efficiency of feeding strategies in calves that respond to changes in feed intake and excretion of minerals during periods of heat stress.

Calves appear to be affected by heat stress already during the embryonic period (Silva et al., 2013). Evidence suggest that maternal heat stress during late gestation results in impaired fetal growth and immune function of the neonate (Tao and Dahl, 2013). Lower serum immunoglobulin and higher serum corticosteroids 
were found in calves exposed to higher temperatures (Stott et al., 1976; Donovan et al., 1986). Bertagnon et al. (2011) found a higher number of monocytes in the blood and a lower number of alveolar giant macrophages in tracheobronchial lavage fluids of calves at high temperatures $\left(30^{\circ} \mathrm{C}\right)$ and low humidity $(41 \%)$, compared with 2 combinations of lower temperature and higher humidity. This suggests that a hot and dry climate suppresses the respiratory immune response. Broucek et al. (2009) investigated the influence of heat stress on hematologic variables and did not find any substantial effect.

\section{INFLUENCE OF HOUSING ON CALVES}

From a performance and welfare perspective, calves should ideally be raised in their TNZ and thermal stress should be minimized (Silanikove, 2000). Housing aims to reduce the effect of climate on animals and can provide a specific microclimate. Calves are raised in a variety of housing systems, including open range, individual pens or hutches, and naturally or mechanically ventilated stables. On the one hand, the choice of a specific housing system depends among other factors on the predominant climate in a region (Webster, 1974). On the other hand, each housing system has its own climatic traits and associated benefits and drawbacks. Together with various other factors such as hygiene, feeding practice, or herd management, the type of housing can play a role as a risk factor in disease transmission (Barrington et al., 2002; Marcé et al., 2010). Because of this close interrelation between climate and housing, housing systems are discussed under a climatic point of view to understand their effect on calves' thermal wellbeing. An overview of selected studies comparing the effect of housing type on calf performance and health is provided in Table 1.

According to surveys conducted in Europe, dairy calves are predominantly housed individually in pens (with possible contact to other calves) or hutches (generally outdoors without direct contact to other calves) during the first 2 to 14 wk of life (Marcé et al., 2010; Klein-Jöbstl et al., 2014). In the United States, 68\% (Walker et al., 2012), and in Canada, 88\% (Vasseur et al., 2010) of preweaned dairy calves are kept in individual pens or hutches.

Recently, the popularity of group housing systems for calves has increased (Wójcik et al., 2012). Group housing is desirable under an animal welfare perspective because it improves cognitive performance (Gaillard et al., 2014), offers more space for movement, and provides better opportunities for social behavior (Jensen and Kyhn, 2000; Chua et al., 2002; von Keyser- lingk et al., 2009). De Paula Vieira et al. (2010) found that preweaned calves housed in pairs consumed more starter and vocalized less in response to weaning than individually housed calves. Intake of starter and ADG are significantly higher in calves paired soon after birth than in late-paired calves (Costa et al., 2015). Some studies claimed that morbidity (Le Neindre, 1993; Hanekamp et al., 1994; Svensson et al., 2003; Svensson and Liberg, 2006; Marcé et al., 2010; Cobb et al., 2014) and mortality (Le Neindre, 1993; Gulliksen et al., 2009b) are higher in group-housed calves than in individually housed calves. These findings, however, depend on many factors such as feeding regimen, management, and environment (Losinger and Heinrichs, 1997; Cobb et al., 2014). Hänninen et al. (2003) and Babu et al. (2009) found a lower incidence of diarrhea in group-reared calves compared with individually reared calves. Kung et al. (1997) observed fewer days of medication in calves raised in a group pen as opposed to individual hutches. The time to manage a calf in a hutch was 10-fold compared with the group pen. Bernal-Rigoli et al. (2012) observed greater DMI and final BW in group-housed calves compared with individually housed calves. Losinger and Heinrichs (1997), Svensson and Liberg (2006), and Babu et al. (2009) all concluded that housing calves in small groups compared with individual housing or large groups was beneficial for calf health and growth.

\section{Open Range}

Calves in cow-calf operations for beef production are often kept on open range where they are directly exposed to local climate and weather, potentially resulting in extreme heat or cold stress. Different structures can help to protect them from climatic conditions, ranging from natural structures (e.g., trees) over simple constructions (e.g., shelter, windbreaks, shades) to special appliances (e.g., fans, sprinklers).

During cold temperatures, protection from wind and the provision of a dry lying area and adequate feed are important (Webster, 1974). A common method to mitigate cold stress is the provision of shelter (Mader, 2003; Van Iaer et al., 2014). Holmes et al. (1978) found that the availability of a shelter resulted in increased weight gains in dairy heifers during winter. Without shelter, the ground is likely to become muddy during periods of high precipitation. Mud can lead to a decreased feed intake if cattle have to walk through it to reach their feeding place (Webster, 1974). Whereas partially enclosed shelters in temperate regions protect animals from cold and hot weather, in tropical climates closed shelters are not recommended because they obstruct natural air flow (Da Silva, 2012; Van Iaer et al., 2014). 
Windbreaks act as a barrier, reducing wind speed and thus convective heat loss (Olson and Wallander, 2002; Van Iaer et al., 2014). Typically, they offer protection from wind along a distance of 5 to 10 times their height (Mader, 2003). The amount of time animals spent behind a windbreak was found to be correlated with wind speed, but not with ambient temperature (Olson and Wallander, 2002). With hot temperatures, however, windbreaks can impair airflow and increase heat stress, resulting in a decreased weight gain of feedlot calves (Mader et al., 1997).

Shades protect animals from direct solar radiation and mitigate heat stress (Mitlöhner et al., 2001; Mader, 2003). Silanikove (2000) recommended providing shade to animals in regions where typical summer temperatures exceed $24^{\circ} \mathrm{C}$. The provision of shade can result in increased weight gains and feed intake (Mitlöhner et al., 2001); however, study results are not unanimous (Coleman et al., 1996; Sullivan et al., 2011). Other cooling methods include sprinkling, misting, and fans. Although many cooling methods have been suggested for adult cattle (Armstrong, 1994; Mitlöhner et al., 2001; West, 2003; Collier et al., 2006; Nienaber and Hahn, 2007; Schütz et al., 2011), literature evaluating cooling methods for calves is scarce. Nonetheless, it is likely that the same methods that have proven to alleviate heat stress in adult cattle, for example, different combinations of shade, sprinkling, and fans (Collier et al., 2006; Nienaber and Hahn, 2007; Schütz et al., 2011), are also effective for calves.

\section{Calf Hutches}

Davis et al. (1954) were among the first researchers studying outdoor individual portable pens and their beneficial role in controlling diseases. They argued that individual outdoor housing offered better hygienic conditions and a lower risk of infection with pathogens for respiratory disease and diarrhea. Today, keeping calves outdoors in pens, hutches, or igloos is a common practice all over the world (Hoshiba, 1986; Schäffer and von Borrell, 2008; Walker et al., 2012). Lower mortality rates (Davis et al., 1954; Waltner-Toews et al., 1986; Wójcik et al., 2012), reduced incidences of respiratory and gastrointestinal diseases (Davis et al., 1954; Okamoto et al., 1993; Nilsson, 2012; Wójcik et al., 2012), as well as higher weight gains (Davis et al., 1954; Richard et al., 1988) were recorded in calf hutches compared with housing in heated stables. Some authors, however, found no or only minor performance differences between both husbandry systems (Jorgenson et al., 1970; Hanekamp et al., 1994). Disadvantages of individual outdoor hutches include the lack of social contact between calves and increased labor cost (Kung et al., 1997).

Hutches and igloos should have a radiation-reflecting surface and be placed with the opening away from the weather side on well-drained ground, preferably under a roof or cover. During winter, only fully dried newborn calves should be placed in outdoor hutches and sufficient dry bedding should be offered (Callan and Garry, 2002; Schäffer and von Borrell, 2008). Several studies analyzed the effect of calf hutch type and material on hutch microclimate, calf performance, and thermal physiology. Macaulay et al. (1995) compared 3 housing types during fall and found that enclosed molded polyethylene domes had the warmest microclimate, followed by conventional wooden hutches and thermomolded opaque polymer hutches. Roof material seemed to have only a minor influence on the thermal comfort of calves (Kawabata et al., 2005; Fonseca et al., 2012).

Air temperature inside hutches is correlated with ambient air temperature but rises with direct solar radiation (Hoshiba, 1986; Spain and Spiers, 1996; Kawabata et al., 2005). Hoshiba (1986) analyzed the microclimate in fiber-reinforced plastic calf hutches during the Japanese winter and recorded temperature and wind speed. Whereas the inside temperature was only $2.5^{\circ} \mathrm{C}$ higher on average than the outside temperature, wind speed in the hutches was reduced considerably. The mean occupancy rate (ratio of time a calf spent inside the hutch to $24 \mathrm{~h}$ ) was 85 to $90 \%$. Occupancy rates of the hutches were positively correlated with high wind speed. Hill et al. (2011) studied climatic parameters inside polyethylene hutches in Ohio during the summer and found the temperature to be $2^{\circ} \mathrm{C}$ higher and the relative humidity to be $8^{\circ} \mathrm{C}$ higher than outside. High relative humidity can cause condensation and result in wet walls, bedding, and hair coat (Abshoff and Steimle, 1983). This suggests that synthetic hutches provide a microclimate that is likely beneficial in cold, rainy, or windy conditions, but could be disadvantageous under hot or humid conditions.

The microclimate in calf hutches can be modified with the help of simple tools, for example by installing fans (Hill et al., 2011), by providing supplemental shade to prevent heat stress (Coleman et al., 1996; Spain and Spiers, 1996; Kawabata et al., 2005), or by elevating one side of the hutch to improve air exhaust (Moore et al., 2012). In a hot climate, however, these methods provide only a limited alleviation of the heat stress effect (Coleman et al., 1996).

In accordance with the increased trend toward group housing, hutches and igloos for groups of calves also have gained in popularity (Nilsson, 2012; Wójcik et al., 2012). Wójcik et al. (2012) compared group housing of 
calves in igloos and in traditional barns and confirmed the advantages of outside housing for calf groups. Calves kept in group igloos exhibited higher weight gains and lower incidence of respiratory disease. Further research is still necessary to fully understand the subtleties of climatic conditions in group hutches.

\section{Indoor Housing}

Calves are often housed in barns, especially in regions with a cold climate (Webster, 1974; Klein-Jöbstl et al., 2014). For example, in Canada $80 \%$ of preweaned calves are kept in the main barn and $12 \%$ in a separate barn (Vasseur et al., 2010).

Basic types of indoor housing systems include closed barns, which are mechanically ventilated, insulated, and often possible to heat, and open, naturally ventilated stables (Hanekamp et al., 1994). Seedorf et al. (1998) recorded climatic conditions over more than 2 yr in 329 livestock buildings in Northern Europe. Calves were predominantly housed in naturally ventilated barns, where the climate was correlated with the outside climate and exhibited a seasonal pattern. The difference between inside and outside temperature decreased with increasing stocking density (Wagner-Storch and Palmer, 2002). Hanekamp et al. (1994), Ertugrul et al. (2000), and Svensson and Liberg (2006) compared open with closed barns as housing options for calves. They found a lower mortality rate, higher growth rates during the rearing period, and a higher feed intake in the open barn.

The microclimate inside a stable is an important component of the overall climatic conditions and is determined by the following factors: air temperature, temperature of stable surfaces, humidity, wind speed, and concentration of noxious gases, dust, and microbes. Potentially noxious gases include $\mathrm{CO}_{2}$, carbon monoxide, $\mathrm{NH}_{3}, \mathrm{H}_{2} \mathrm{~S}$, and methane. A temperature of 16 to $20^{\circ} \mathrm{C}$ for calves with a BW of up to $60 \mathrm{~kg}$ and 10 to $20^{\circ} \mathrm{C}$ for calves weighing 60 to $150 \mathrm{~kg}$ are recommended by the German Institute for Standardization (DIN, 1992). Relative humidity should be 60 to $80 \%$ in mechanically ventilated stables and 40 to $70 \%$ in heated stables (DIN, 1992).

One of the many risk factors for respiratory disease is poor air quality. Especially in closed barns without proper ventilation, air quality, pathogen concentration, and associated diseases are often problematic (Barrington et al., 2002; Lago et al., 2006). Many airborne bovine viruses (e.g., bovine herpesvirus 1, bovine parainfluenza virus type 3 , bovine respiratory syncytial virus, and bovine viral diarrhea virus) and gramnegative bacteria are hydrophobic and survive better in dry air, whereas increased survival time of most other pathogens is associated with high humidity (Callan and Garry, 2002; Nordlund, 2008). Pritchard et al. (1981) established a link between air quality and incidence as well as severity of bovine respiratory disease (BRD) in confined sheds. In sheds equipped with an air filtration device, airborne bacterial concentration, antibiotic treatment for $\mathrm{BRD}$, and area of lung consolidation at slaughter were reduced significantly compared with the control treatment (no air filtration). Weight gain was reduced in diseased calves. Lago et al. (2006) evaluated the effect of air quality on the respiratory health of calves in 13 naturally ventilated barns during winter (average temperature $4^{\circ} \mathrm{C}$ ). High bacterial density, physical contact between calves, and a low nesting score (indicative for shallow depth of bedding) were associated with an increased prevalence of respiratory disease. Therefore, the authors recommended providing sufficient bedding to reduce cold stress in calves. Nonnecke et al. (2009) observed higher respiratory scores and a higher quantity of prescribed antibiotics in calves kept in a cold, wet environment than in a warm, dry environment. Brscic et al. (2012) investigated the prevalence of BRD in veal calves in a cross-sectional study on 174 farms in Europe. The main risk factors identified were cold climate, mechanical ventilation, and drafts. Further studies evaluating the incidence of respiratory disease in different housing systems are listed in Table 1.

Diarrhea is another common disease in calves. Many enteric pathogens are transmitted by the fecaloral route; however, some infectious agents are also transmitted through aerosols. Environmental risk factors include climatic conditions (Barrington et al., 2002; Gulliksen et al., 2009a), housing (Gulliksen et al., 2009a; Klein-Jöbstl et al., 2014), stocking density (Frank and Kaneene, 1993; Barrington et al., 2002), and hygiene (Frank and Kaneene, 1993; Klein-Jöbstl et al., 2014). Still, the influence of the housing system on diarrheal incidence is less obvious than on the incidence of respiratory diseases (Table 1). Housing on noncontaminated ground, appropriate air quality, and ventilation are important for the enteric health of calves (Barrington et al., 2002). Hänninen et al. (2003) found a lower incidence of diarrhea in preweaned calves housed indoors in small groups compared with calves housed outdoors with or without shelter. Klein-Jöbstl et al. (2014) observed a greater odds ratio for diarrhea in Austrian dairy calves kept outdoors in igloos than in calves kept in individual pens in a barn. This observation was possibly contributed to the low temperatures and temperature fluctuations the igloo-raised calves were exposed to.

Frequent ventilation of barns is essential to supply fresh air and to minimize the amount of humidity and 
airborne contaminants in the barn air. Pathogen concentration and the amount of pathogens inhaled were shown to decrease with air temperature (Callan and Garry, 2002; Nordlund, 2008). Hillman et al. (1992) installed a positive pressure ventilation system in a calf nursery that filtered air particles larger than 0.5 $\mu \mathrm{m}$ and supplied fresh air to the nursery depending on interior temperature, humidity, and ammonia level. They concluded that the ventilation system mimicked outside air conditions and greatly reduced respiratory disease in calves. A minimum air exchange rate of 6 changes per hour at a capacity of $6 \mathrm{~m}^{3}$ per calf (Wathes et al., 1983) or $0.35 \mathrm{~m}^{3} \cdot \mathrm{h}^{-1} \cdot \mathrm{kg}^{-1}$ should be reached. Depending on the input variables, much higher (10 to 15 $\times$ minimum rate) air changes might be necessary during summer (Turnbull, 1980; Charles, 1994). Whereas appropriate ventilation is necessary to control humidity and airborne pathogens, drafts with air velocities of over $0.2 \mathrm{~m} / \mathrm{s}$ with low temperatures and over $0.6 \mathrm{~m} / \mathrm{s}$ with high temperatures should be avoided (DIN, 1992). In winter, there is often a tradeoff between supplying fresh air and maintaining an adequate temperature (Callan and Garry, 2002; Nordlund, 2008). With very low outside temperatures, supplementary heating might be necessary (Turnbull, 1980). Nordlund (2008) recommended the use of positive-pressure ventilation systems to ensure a sufficient supply of fresh air in individual calf pens. This can be achieved by installing a fan that supplies external air to a distribution duct system, which delivers the fresh air to the individual pens.

In conclusion, popular housing systems for raising dairy calves are currently being challenged and more group-housing options are being explored. Enclosed stables allow for the greatest modification of outdoor climate, but it is generally agreed that outdoor housing offers better air quality and hygienic conditions. In open barns it is important to offer calves a draft-free microclimate with adequate bedding.

\section{CONCLUSIONS}

The discussion of housing systems and disease incidence in this review is limited to climatic aspects and does not intend to cover the full complexity of these subjects. Whereas various studies have been published on thermoregulation or thermic stress in general, this review is focused on the influence of climatic conditions on the performance and health of calves. Thermoregulation in calves is similar to that in adult cattle, but young calves are more prone to heat loss. Vital calves are born with functional thermoregulatory mechanisms and are remarkably cold tolerant under adequate management conditions. In dystocial calves, heat generation mechanisms are often impaired. Under cold conditions, the feeding regimen should provide sufficient energy for heat production. Thermic stress is observed in association with extreme temperatures and large temperature variations, but other variables such as relative humidity and wind speed might also contribute to thermic stress. Whereas the tolerance of calves toward cold and the tolerance of adult cattle or dairy cows toward heat is well researched, studies regarding the thermoregulation of calves under hot conditions are scare. Housing reduces the effect of climate on calves and can provide them with a beneficial microclimate. Cold stress in outdoor housing systems can be reduced by offering shelter or windbreaks. Limited results for alleviating heat stress can be achieved by simple measures, such as the provision of shade and easily accessible drinking water. Depending on the housing system, additional thermic stress relieving strategies might be warranted. Common individual housing systems for raising dairy calves are currently being challenged. Group housing is becoming more popular and desirable with regard to animal welfare and health aspects. More research is required to fully understand the ideal housing system for calves under different environmental and management conditions. Whatever the housing system, it is essential to offer calves a clean and dry environment with shelter from drafts, precipitation, and extreme solar radiation.

\section{ACKNOWLEDGMENTS}

The authors received no funding or financial support for the research, authorship, or publication of this article.

\section{REFERENCES}

Abshoff, A., and F. Steimle. 1983. Das biologische Klima im Kälberstall, Teil 1: Die Ansprüche des Kalbes an das Klima - präzisiert in physikalischen Größen. Grundlagen der Landtechnik 33:161-192.

Alexander, G., J. W. Bennett, and R. T. Gemmell. 1975. Brown adipose tissue in the new-born calf (Bos taurus). J. Physiol. 244:223234.

Armstrong, D. V. 1994. Heat stress interaction with shade and cooling. J. Dairy Sci. 77:2044-2050.

Azzam, S. M., J. E. Kinder, M. K. Nielsen, L. A. Werth, K. E. Gregory, L. V. Cundiff, and R. M. Koch. 1993. Environmental effects on neonatal mortality of beef calves. J. Anim. Sci. 71:282-290.

Babu, L. K., H. Pandey, R. C. Patra, and A. Sahoo. 2009. Hematobiochemical changes, disease incidence and live weight gain in individual versus group reared calves fed on different levels of milk and skim milk. Anim. Sci. J. 80:149-156.

Bandell, M., L. J. Macpherson, and A. Patapoutian. 2007. From chills to chilis: Mechanisms for thermosensation and chemesthesis via thermoTRPs. Curr. Opin. Neurobiol. 17:490-497.

Barrington, G. M., J. M. Gay, and J. F. Evermann. 2002. Biosecurity for neonatal gastrointestinal diseases. Vet. Clin. North Am. Food Anim. Pract. 18:7-34.

Beede, D. K., and R. J. Collier. 1986. Potential nutritional strategies for intensively managed cattle during thermal stress. J. Anim. Sci. 62:543-554. 
Berman, A. 2003. Effects of body surface area estimates on predicted energy requirements and heat stress. J. Dairy Sci. 86:3605-3610.

Berman, A., and J. Zamsky. 1971. Thermoregulatory control in cattle exposed to the natural climate. J. Dairy Sci. 54:1216-1218.

Bernal-Rigoli, J. C., J. D. Allen, J. A. Marchello, S. P. Cuneo, S. R. Garcia, G. Xie, L. W. Hall, C. D. Burrows, and G. C. Duff. 2012. Effects of housing and feeding systems on performance of neonatal Holstein bull calves. J. Anim. Sci. 90:2818-2825.

Bertagnon, H. G., G. V. Z. Esper, M. P. Emanuelli, and L. G. Pellegrine. 2011. Influência meteorológica no leucograma e na população citológica do trato respiratório de bezerros. Pesqui. Vet. Bras. 31:244-246.

Bligh, J. 1998. Mammalian homeothermy: An integrative thesis. J. Therm. Biol. 23:143-258.

Borderas, F. T., A. M. B. de Passillé, and J. Rushen. 2009. Temperature preferences and feed level of the newborn dairy calf. Appl. Anim. Behav. Sci. 120:56-61.

Brosh, A., Y. Aharoni, A. A. Degen, D. Wright, and B. A. Young. 1998. Effects of solar radiation, dietary energy, and time of feeding on thermoregulatory responses and energy balance in cattle in a hot environment. J. Anim. Sci. 76:2671-2677.

Broucek, J., P. Kisac, and M. Uhrincat. 2009. Effect of hot temperatures on the hematological parameters, health and performance of calves. Int. J. Biometeorol. 53:201-208.

Broucek, J., P. Kisac, M. Uhrincat, A. Hanus, and F. Benc. 2008. Effect of high temperature on growth performance of calves maintained in outdoor hutches. J. Anim. Feed Sci. 17:139-146.

Brown-Brandl, T. M., R. A. Eigenberg, G. L. Hahn, J. A. Nienaber, T. L. Mader, D. E. Spiers, and A. M. Parkhurst. 2005. Analyses of thermoregulatory responses of feeder cattle exposed to simulated heat waves. Int. J. Biometeorol. 49:285-296.

Brown-Brandl, T. M., J. A. Nienaber, R. A. Eigenberg, G. L. Hahn, and H. Freetly. 2003. Thermoregulatory responses of feeder cattle. J. Therm. Biol. 28:149-157.

Brscic, M., H. Leruste, L. F. M. Heutinck, E. A. M. Bokkers, M. Wolthuis-Fillerup, N. Stockhofe, F. Gottardo, B. J. Lensink, G. Cozzi, and C. G. Van Reenen. 2012. Prevalence of respiratory disorders in veal calves and potential risk factors. J. Dairy Sci. 95:2753-2764.

Callan, R. J., and F. B. Garry. 2002. Biosecurity and bovine respiratory disease. Vet. Clin. North Am. Food Anim. Pract. 18:57-77.

Cartwright, T. C. 1955. Responses of beef cattle to high ambient temperatures. J. Anim. Sci. 14:350-362.

Charles, D. R. 1994. Comparative climatic requirements. Pages 3-24 in Livestock Housing. 1st ed. C. M. Wathes and D. R. Charles, ed. CAB International University Press, Cambridge, UK.

Christison, G. I., and H. D. Johnson. 1972. Cortisol turnover in heatstressed cows. J. Anim. Sci. 35:1005-1010.

Chua, B., E. Coenen, J. Van Delen, and D. M. Weary. 2002. Effects of pair versus individual housing on the behavior and performance of dairy calves. J. Dairy Sci. 85:360-364.

Coban, O., and N. Sabuncuoglu. 2005. Blood characteristics of dairy calves as affected by age, breed and types of barn. JAVA 4:459-461.

Cobb, C. J., B. S. Obeidat, M. D. Sellers, A. R. Pepper-Yowell, and M. A. Ballou. 2014. Group housing of Holstein calves in a poor indoor environment increases respiratory disease but does not influence performance or leukocyte responses. J. Dairy Sci. 97:3099-3109.

Coleman, D. A., B. R. Moss, and T. A. McCaskey. 1996. Supplemental shade for dairy calves reared in commercial calf hutches in a southern climate. J. Dairy Sci. 79:2038-2043.

Collier, R. J., D. K. Beede, W. W. Thatcher, L. A. Israel, and C. J. Wilcox. 1982. Influences of environment and its modification on dairy animal health and production. J. Dairy Sci. 65:2213-2227.

Collier, R. J., G. E. Dahl, and M. J. VanBaale. 2006. Major advances associated with environmental effects on dairy cattle. J. Dairy Sci. 89:1244-1253.

Costa, J. H. C., R. K. Meagher, M. A. G. von Keyserlingk, and D. M. Weary. 2015. Early pair housing increases solid feed intake and weight gains in dairy calves. J. Dairy Sci. 98:6381-6386.
Craig, A. D., M. C. Bushnell, E.-T. Zhang, and A. Blomqvist. 1994. A thalamic nucleus specific for pain and temperature sensation. Nature 372:770-773.

Cruz, A. M., and J. M. Naylor. 1993. A retrospective study of frostbite injuries in calves (1982-1991). Can. Vet. J. 34:306-308.

Da Silva, R. G. 2012. Weather and climate and animal production. Pages 1-21 in Guide to Agricultural Meteorological Practices. Vol. 134. World Meteorological Organization, Geneva, Switzerland.

Davis, L. R., K. M. Autrey, H. Herlich, and G. E. Hawkins Jr.. 1954 Outdoor individual portable pens compared with conventional housing for raising dairy calves. J. Dairy Sci. 37:562-570.

De Paula Vieira, A., M. A. G. von Keyserlingk, and D. M. Weary. 2010. Effects of pair versus single housing on performance and behavior of dairy calves before and after weaning from milk. J. Dairy Sci. 93:3079-3085.

Diesch, T. J., D. J. Mellor, K. J. Stafford, and R. N. Ward. 2004a. Blood metabolites and body temperature of single calves between 1 and 4 days of age in a dairy herd in New Zealand. N. Z. Vet. J. $52: 256-260$.

Diesch, T. J., D. J. Mellor, K. J. Stafford, and R. N. Ward. 2004b. The physiological and physical status of single calves at birth in a dairy herd in New Zealand. N. Z. Vet. J. 52:250-255.

DIN. 1992. Wärmeschutz geschlossener Ställe. Vol. 18 910. Deutsches Institut für Normung (German Institute for Standadization), Berlin, Germany.

Donovan, G. A., L. Badinga, R. J. Collier, C. J. Wilcox, and R. K. Braun. 1986. Factors influencing passive transfer in dairy calves. J. Dairy Sci. 69:754-759.

Donovan, G. A., I. R. Dohoo, D. M. Montgomery, and F. L. Bennett. 1998. Calf and disease factors affecting growth in female Holstein calves in Florida, USA. Prev. Vet. Med. 33:1-10.

Eberhardt, B. G., R. A. Satrapa, C. R. L. Capinzaiki, L. A. Trinca, and C. M. Barros. 2009. Influence of the breed of bull (Bos taurus indicus vs. Bos taurus taurus) and the breed of cow (Bos taurus indicus, Bos taurus taurus and crossbred) on the resistance of bovine embryos to heat. Anim. Reprod. Sci. 114:54-61.

Egli, C. P., and J. W. Blum. 1998. Clinical, haematological, metabolic and endocrine traits during the first three months of life of suckling Simmentaler calves held in a cow-calf operation. J. Vet. Med. A 45:99-118.

Ehrenreich, J. H., and A. J. Bjugstad. 1966. Cattle grazing time is related to temperature and humidity. J. Range Manage. 19:141-142.

Ertugrul, O., O. Alpan, N. Unal, and F. Azeroglu. 2000. Growth and survival of Holstein and Brown Swiss calves reared outdoors in individual hutches. Trop. Anim. Health Prod. 32:257-266.

Finch, V. A. 1986. Body temperature in beef cattle: Its control and relevance to production in the tropics. J. Anim. Sci. 62:531-542.

Findlay, J. D. 1957. The respiratory activity of calves subjected to thermal stress. J. Physiol. 136:300-309.

Fonseca, P. C. F., E. A. Almeida, and R. Passini. 2012. Evaluation of covering materials in individual shelters and its effects on physiological responses and performance of dairy calves. Engenharia Agrícola 32:1041-1047.

Frank, N. A., and J. B. Kaneene. 1993. Management risk factors associated with calf diarrhea in Michigan dairy herds. J. Dairy Sci. 76:1313-1323.

Gaillard, C., R. K. Meagher, M. A. G. von Keyserlingk, D. M. Weary and A. McElligott. 2014. Social housing improves dairy calves performance in two cognitive tests. PLoS ONE9:e90205.

Gaughan, J. B., T. L. Mader, S. M. Holt, G. L. Hahn, and B. A. Young. 2002. Review of current assessment of cattle and microclimate during periods of high heat load. Animal Production Australia 24:77-80.

Gluckman, P. D., S. V. Sizonenko, and N. S. Bassett. 1999. The transition from fetus to neonate-An endocrine perspective. Acta Paediatr. Suppl. 88:7-11.

Godfrey, R. W., S. D. Smith, M. J. Guthrie, R. L. Stanko, D. A. Neuendorff, and R. D. Randel. 1991. Physiological responses of newborn Bos indicus and Bos indicus $\times$ Bos taurus calves after exposure to cold. J. Anim. Sci. 69:258-263. 
Gonzalez-Jimenez, E., and K. L. Blaxter. 1962. The metabolism and thermal regulation of calves in the first month of life. Br. J. Nutr. 16:199-212.

Gorden, P. J., and P. Plummer. 2010. Control, management, and prevention of bovine respiratory disease in dairy calves and cows. Vet. Clin. North Am. Food Anim. Pract. 26:243-259.

Grongnet, J. F., E. Grongnet-Pinchon, A. Witowski, D. Chevrel, R. Garnier, J. Lareynie, and M. Lesage. 1985. Neonatal levels of plasma thyroxine in male and female calves fed a colostrum or immunoglobulin diet or fasted for the first 28 hours of life. Reprod. Nutr. Dev. 25:537-543.

Gulliksen, S. M., E. Jor, K. I. Lie, I. S. Hamnes, T. Løken, J. Åkerstedt, and O. Østerås. 2009a. Enteropathogens and risk factors for diarrhea in Norwegian dairy calves. J. Dairy Sci. 92:5057-5066.

Gulliksen, S. M., K. I. Lie, T. Løken, and O. Østerås. 2009b. Calf mortality in Norwegian dairy herds. J. Dairy Sci. 92:2782-2795.

Hadorn, U., H. Hammon, R. M. Bruckmaier, and J. W. Blum. 1997. Delaying colostrum intake by one day has important effects on metabolic traits and on gastrointestinal and metabolic hormones in neonatal calves. J. Nutr. 127:2011-2023.

Hahn, G. L., R. A. Eigenberg, J. A. Nienaber, and E. T. Littledike. 1990. Measuring physiological responses of animals to environmental stressors using a microcomputer-based portable datalogger. J. Anim. Sci. 68:2658-2665.

Hammon, H. M., and J. W. Blum. 1998. Metabolic and endocrine traits of neonatal calves are influenced by feeding colostrum for different durations or only milk replacer. J. Nutr. 128:624-632.

Hammon, H. M., J. Steinhoff-Wagner, U. Schönhusen, C. C. Metges, and J. W. Blum. 2012. Energy metabolism in the newborn farm animal with emphasis on the calf: Endocrine changes and responses to milk-born and systemic hormones. Domest. Anim. Endocrinol. 43:171-185.

Hanekamp, W. J. A., A. C. Smits, and H. K. Wierenga. 1994. Open versus closed barn and individual versus group-housing for bull calves destined for beef production. Livest. Prod. Sci. 37:261-270.

Hänninen, L., H. Hepola, J. Rushen, A. M. De Passille, P. Pursiainen, V.-M. Tuure, L. Syrjälä-Qvist, M. Pyykkönen, and H. Saloniemi. 2003. Resting behaviour, growth and diarrhoea incidence rate of young dairy calves housed individually or in groups in warm or cold buildings. Acta Agric. Scand. Anim. Sci. 53:21-28.

Hepola, H., L. Hänninen, P. Pursiainen, V.-M. Tuure, L. Syrjälä-Qvist, M. Pyykkönen, and H. Saloniemi. 2006. Feed intake and oral behaviour of dairy calves housed individually or in groups in warm or cold buildings. Livest. Sci. 105:94-104.

Hill, T. M., H. G. Bateman, J. M. Aldrich, and R. L. Schlotterbeck. 2011. Comparisons of housing, bedding, and cooling options for dairy calves. J. Dairy Sci. 94:2138-2146.

Hillman, P., K. Gebremedhin, and R. Warner. 1992. Ventilation system to minimize airborne bacteria, dust, humidity, and ammonia in calf nurseries. J. Dairy Sci. 75:1305-1312.

Holmes, C. W., R. Christensen, N. A. McLean, and J. Lockyer. 1978. Effects of winter weather on the growth rate and heat production of dairy cattle. N. Z. J. Agric. Res. 21:549-556.

Hoshiba, S. 1986. Environmental characteristics of calf hutches. J. Fac. Agric. Hokkaido Univ. 63:64-103.

IUPS. 2001. Glossary of terms for thermal physiology. Jpn. J. Physiol. $51: 245-280$.

Ivanov, K. P. 2006. The development of the concepts of homeothermy and thermoregulation. J. Therm. Biol. 31:24-29.

Jaster, E. H., G. C. McCoy, and R. L. Fernando. 1990. Dietary fat in milk or milk replacers for dairy calves raised in hutches during the winter. J. Dairy Sci. 73:1843-1850.

Jensen, M. B., and R. Kyhn. 2000. Play behaviour in group-housed dairy calves, the effect of space allowance. Appl. Anim. Behav. Sci. 67:35-46.

Jorgenson, L. J., N. A. Jorgensen, D. J. Schingoethe, and M. J. Owens. 1970. Indoor versus outdoor calf rearing at three weaning ages. J. Dairy Sci. 53:813-816.

Kawabata, C. Y., R. C. Castro, and H. Savastano Júnior. 2005. Thermal comfort indexes and physiological responses of Holstein calves in individual houses with different roofings. Engenharia Agrícola 25:598-607.

Khalifa, H. H. 2003. Bioclimatology and adaptation of farm animals in a changing climate. Pages $15-30$ in Interactions between Climate and Animal Production. 1st ed. N. Lacetera, U. Bernabucci, H. H. Khalifa, B. Ronchi, and A. Nardone, ed. Wageningen Academic Publishers, Wageningen, the Netherlands.

King, J. M., D. J. Parsons, J. R. Turnpenny, J. Nyangaga, P. Bakari, and C. M. Wathes. 2006. Modelling energy metabolism of Friesians in Kenya smallholdings shows how heat stress and energy deficit constrain milk yield and cow replacement rate. Anim. Sci. 82:705-716

Kirch, B. H., G. E. Aiken, and D. E. Spiers. 2008. Temperature influences upon vascular dynamics in cattle measured by Doppler ultrasonography. J. Therm. Biol. 33:375-379.

Klein-Jöbstl, D., M. Iwersen, and M. Drillich. 2014. Farm characteristics and calf management practices on dairy farms with and without diarrhea: A case-control study to investigate risk factors for calf diarrhea. J. Dairy Sci. 97:5110-5119.

Klemm, G. H., and K. W. Robinson. 1955. The heat tolerance of two breeds of calves from 1 to 12 months of age. Crop Pasture Sci. $6: 350-364$.

Kobayashi, S., M. Okazawa, A. Hori, K. Matsumura, and H. Hosokawa. 2006. Paradigm shift in sensory system-Animals do not have sensors. J. Therm. Biol. 31:19-23.

Krastev, K. 2002. Influence of the environmental temperature and humidity regime during winter over some adaptive reactions of calves. Biotechnology in Animal Husbandry 18:11-16.

Kregel, K. C. 2002. Invited review: Heat shock proteins: Modifying factors in physiological stress responses and acquired thermotolerance. J. Appl. Physiol. 92:2177-2186.

Kung, L., S. Demarco, L. N. Siebenson, E. Joyner, G. F. W. Haenlein, and R. M. Morris. 1997. An evaluation of two management systems for rearing calves fed milk replacer. J. Dairy Sci. 80:2529-2533.

Lago, A., S. M. McGuirk, T. B. Bennett, N. B. Cook, and K. V. Nordlund. 2006. Calf respiratory disease and pen microenvironments in naturally ventilated calf barns in winter. J. Dairy Sci. 89:4014-4025.

Le Neindre, P. 1993. Evaluating housing systems for veal calves. J. Anim. Sci. 71:1345-1354.

Lee, C. Y., H. H. Head, C. R. Feinstein, J. Hayen, and F. A. Simmen. 1995. Endocrine changes and circulating insulin-like growth factors in newborn calves fed colostrum, milk or milk replacer. Asian J. Anim. Sci. 8:51-58

Litherland, N. B., D. Da Silva, R. LaBerge, J. Schefers, and A. Kertz. 2014. Supplemental fat for dairy calves during mild cold stress. J. Dairy Sci. 97:2980-2989.

Losinger, W. C., and A. J. Heinrichs. 1997. Management practices associated with high mortality among preweaned dairy heifers. J Dairy Res. 64:1-11.

Lumpkin, E. A., and M. J. Caterina. 2007. Mechanisms of sensory transduction in the skin. Nature 445:858-865.

Macaulay, A. S., G. L. Hahn, D. H. Clark, and D. V. Sisson. 1995. Comparison of calf housing types and tympanic temperature rhythms in Holstein calves. J. Dairy Sci. 78:856-862.

Mader, T. L. 2003. Environmental stress in confined beef cattle. J. Anim. Sci. 81:E110-E119.

Mader, T. L., J. M. Dahlquist, and J. B. Gaughan. 1997. Wind protection effects and airflow patterns in outside feedlots. J. Anim. Sci. 75:26-36.

Mader, T. L., S. M. Holt, G. L. Hahn, M. S. Davis, and D. E. Spiers. 2002. Feeding strategies for managing heat load in feedlot cattle. J. Anim. Sci. 80:2373-2382.

Marcé, C., R. Guatteo, N. Bareille, and C. Fourichon. 2010. Dairy calf housing systems across Europe and risk for calf infectious diseases. Animal 4:1588-1596.

Martin, S. W., C. W. Schwabe, and C. E. Franti. 1975. Dairy calf mortality rate: The association of daily meteorological factors and calf mortality. Can. J. Comp. Med. 39:377-388.

McDowell, R. E. 1985. Crossbreeding in tropical areas with emphasis on milk, health, and fitness. J. Dairy Sci. 68:2418-2435. 
McDowell, R. E., J. C. Wilk, and C. W. Talbott. 1996. Economic viability of crosses of Bos taurus and Bos indicus for dairying in warm climates. J. Dairy Sci. 79:1292-1303.

McKnight, D. R. 1978. Performance of newborn dairy calves in hutch housing. Can. J. Anim. Sci. 58:517-520.

McLean, J. A. 1963. The partition of insensible losses of body weight and heat from cattle under various climatic conditions. J. Physiol. $167: 427-447$

Mitlöhner, F. M., J. L. Morrow, J. W. Dailey, S. C. Wilson, M. L. Galyean, M. F. Miller, and J. J. McGlone. 2001. Shade and water misting effects on behavior, physiology, performance, and carcass traits of heat-stressed feedlot cattle. J. Anim. Sci. 79:2327-2335.

Moore, D. A., J. L. Duprau, and J. R. Wenz. 2012. Short communication: Effects of dairy calf hutch elevation on heat reduction, carbon dioxide concentration, air circulation, and respiratory rates. J. Dairy Sci. 95:4050-4054.

Moran, J. 2002. Calf Rearing-A Practical Guide. 2nd ed. Landlinks Press, Collingwood, Australia.

Morrison, S. F. 2004. Central pathways controlling brown adipose tissue thermogenesis. News Physiol. Sci. 19:67-74.

Morrison, S. F., and K. Nakamura. 2011. Central neural pathways for thermoregulation. Front. Biosci. 16:74-104.

Murley, W. R., and E. W. Culvahouse. 1958. Open shed and portable pens versus conventional housing for young dairy calves. J. Dairy Sci. 41:977-981.

Nagashima, K., S. Nakai, M. Tanaka, and K. Kanosue. 2000. Neuronal circuitries involved in thermoregulation. Auton. Neurosci. $85: 18-25$

Neuwirth, J. G., J. K. Norton, C. A. Rawlings, F. N. Thompson, and G. O. Ware. 1979. Physiologic responses of dairy calves to environmental heat stress. Int. J. Biometeorol. 23:243-254.

Nienaber, J. A., and G. L. Hahn. 2007. Livestock production system management responses to thermal challenges. Int. J. Biometeorol. $52: 149-157$.

Nienaber, J. A., G. L. Hahn, and R. A. Eigenberg. 1999. Quantifying livestock responses for heat stress management: A review. Int. J. Biometeorol. 42:183-188.

Nilsson, A. 2012. Calf health before and after change in housing system-Isolated barn vs. hutches. Pages 1-35 in Animal Environment and Health. Swedish University of Agricultural Sciences, Skara, Sweden.

Nonnecke, B. J., M. R. Foote, B. L. Miller, M. Fowler, T. E. Johnson, and R. L. Horst. 2009. Effects of chronic environmental cold on growth, health, and select metabolic and immunologic responses of preruminant calves. J. Dairy Sci. 92:6134-6143.

Nordlund, K. V. 2008. Practical considerations for ventilating calf barns in winter. Vet. Clin. North Am. Food Anim. Pract. 24:41-54.

NRC. 2001. Nutrient Requirements of Dairy Cattle. 7th ed. National Academy Press, Washington DC.

Okamoto, M., A. Sone, and S. Hoshiba. 1993. Comparison of performances of young calves in several housing systems in the winter of cold regions. Asian-australas. J. Anim. Sci. 6:305-311.

Olson, B. E., and R. T. Wallander. 2002. Influence of winter weather and shelter on activity patterns of beef cows. Can. J. Anim. Sci. 82:491-501.

Olson, D. P., C. J. Papasian, and R. C. Ritter. 1980a. The effects of cold stress on neonatal calves. I. Clinical condition and pathological lesions. Can. J. Comp. Med. 44:11-18.

Olson, D. P., C. J. Papasian, and R. C. Ritter. 1980b. The effects of cold stress on neonatal calves. II. Absorption of colostral immunoglobulins. Can. J. Comp. Med. 44:19-23.

Olson, D. P., R. C. Ritter, C. J. Papasian, and S. Gutenberger. 1981. Sympathoadrenal and adrenal hormonal responses of newborn calves to hypothermia. Can. J. Comp. Med. 45:321-326.

Piccione, G., G. Caola, and R. Refinetti. 2003. Daily and estrous rhythmicity of body temperature in domestic cattle. BMC Physiol. 3:7.

Pritchard, D. G., C. A. Carpenter, S. P. Morzaria, J. W. Harkness, M. S. Richards, and J. I. Brewer. 1981. Effect of air filtration on respiratory disease in intensively housed veal calves. Vet. Rec. 109:5-9.
Rawson, R. E., H. E. Dziuk, A. L. Good, J. F. Anderson, D. W. Bates, and G. R. Ruth. 1989a. Thermal insulation of young calves exposed to cold. Can. J. Vet. Res. 53:275-278.

Rawson, R. E., H. E. Dziuk, A. L. Good, J. F. Anderson, D. W. Bates, G. R. Ruth, and R. C. Serfass. 1989b. Health and metabolic responses of young calves housed at $-30^{\circ} \mathrm{C}$ to $-8^{\circ} \mathrm{C}$. Can. J. Vet. Res. 53:268-274.

Richard, A. L., L. D. Muller, and A. J. Heinrichs. 1988. Ad libitum or twice daily feeding of acidified milk replacer to calves housed individually in warm and cold environments. J. Dairy Sci. 71:21932202.

Richet, E., M.-J. Davicco, and J.-P. Barlet. 1985. Plasma catecholamine concentrations in lambs and calves during the perinatal period. Reprod. Nutr. Dev. 25:1007-1016.

Robinson, J. B., D. R. Ames, and G. A. Milliken. 1986. Heat production of cattle acclimated to cold, thermoneutrality and heat when exposed to thermoneutrality and heat stress. J. Anim. Sci. 62:1434-1440.

Robinson, J. B., and B. A. Young. 1988. Metabolic heat production of neonatal calves during hypothermia and recovery. J. Anim. Sci. $66: 2538-2544$

Robinson, N. E. 2013. Thermoregulation. Pages 559-568 in Cunningham's Textbook of Veterinary Physiology. 5th ed. B. G. Klein, ed. Elsevier Health Sciences, St. Louis, MO.

Romanovsky, A. A. 2007. Thermoregulation: Some concepts have changed. Functional architecture of the thermoregulatory system. Am. J. Physiol. Regul. Integr. Comp. Physiol. 292:R37-R46.

Roy, J. H. B. 1980. Factors affecting susceptibility of calves to disease. J. Dairy Sci. 63:650-664.

Roy, K. S., and R. J. Collier. 2012. Regulation of acclimation to environmental stress. Pages 49-64 in Environmental Physiology of Livestock. 1st ed. R. J. Collier, ed. John Wiley \& Sons, Chichester, UK.

Rutledge, J. J. 2001. Greek temples, tropical kine and recombination load. Livest. Prod. Sci. 68:171-179.

Schäffer, D., and E. von Borrell. 2008. Kritische Kontrollpunkte (CCP) in der Außenhaltung von Kälbern. Züchtungskunde 80:291-302.

Schepers, R. J., and M. Ringkamp. 2010. Thermoreceptors and thermosensitive afferents. Neurosci. Biobehav. Rev. 34:177-184.

Schingoethe, D. J., D. P. Casper, J. K. Drackley, and F. C. Ludens. 1986. Increased solids intake and feeding frequency for calves in hutches during cold weather. J. Dairy Sci. 69:1063-1069.

Schrama, J. W., A. Arieli, H. A. Brandsma, P. Luiting, and M. W. Verstegen. 1993a. Thermal requirements of young calves during standing and lying. J. Anim. Sci. 71:3285-3292.

Schrama, J. W., A. Arieli, W. Van der Hel, and M. W. Verstegen. 1993b. Evidence of increasing thermal requirement in young, unadapted calves during 6 to 11 days of age. J. Anim. Sci. 71:17611766.

Schrama, J. W., J. P. Noordhuizen, A. Arieli, H. A. Brandsma, J. M. Van der Linden, and M. W. Verstegen. 1994. Circadian fluctuation in heat production of young calves at different ambient temperatures in relation to posture. J. Anim. Sci. 72:598-605.

Schüller, L. K., O. Burfeind, and W. Heuwieser. 2013. Short communication: Comparison of ambient temperature, relative humidity, and temperature-humidity index between on-farm measurements and official meteorological data. J. Dairy Sci. 96:7731-7738.

Schütz, K. E., A. R. Rogers, N. R. Cox, J. R. Webster, and C. B. Tucker. 2011. Dairy cattle prefer shade over sprinklers: Effects on behavior and physiology. J. Dairy Sci. 94:273-283.

Scibilia, L. S., L. D. Muller, R. S. Kensinger, T. F. Sweeney, and P. R. Shellenberger. 1987. Effect of environmental temperature and dietary fat on growth and physiological responses of newborn calves. J. Dairy Sci. 70:1426-1433.

Scott, S. L., R. J. Christopherson, J. R. Thompson, and V. E. Baracos. 1993. The effect of a cold environment on protein and energy metabolism in calves. Br. J. Nutr. 69:127-139.

Seedorf, J., J. Hartung, M. Schröder, K. H. Linkert, S. Pedersen, H. Takai, J. O. Johnsen, J. H. M. Metz, P. W. G. Groot Koerkamp, 
G. H. Uenk, V. R. Phillips, M. R. Holden, R. W. Sneath, J. L. Short, R. P. White, and C. M. Wathes. 1998. Temperature and moisture conditions in livestock buildings in Northern Europe. J. Agric. Eng. Res. 70:49-57.

Silanikove, N. 2000. Effects of heat stress on the welfare of extensively managed domestic ruminants. Livest. Prod. Sci. 67:1-18.

Silva, C. F., E. S. Sartorelli, A. C. S. Castilho, R. A. Satrapa, R. Z. Puelker, E. M. Razza, J. S. Ticianelli, H. P. Eduardo, B. Loureiro, and C. M. Barros. 2013. Effects of heat stress on development, quality and survival of Bos indicus and Bos taurus embryos produced in vitro. Theriogenology 79:351-357.

Snowder, G. D., L. D. Van Vleck, L. V. Cundiff, and G. L. Bennett. 2006. Bovine respiratory disease in feedlot cattle: Environmental, genetic, and economic factors. J. Anim. Sci. 84:1999-2008.

Spain, J. N., and D. E. Spiers. 1996. Effects of supplemental shade on thermoregulatory response of calves to heat challenge in a hutch environment. J. Dairy Sci. 79:639-646.

Spiers, D. E. 2012. Physiological basics of temperature regulation in domestic animals. Pages 17-34 in Environmental Physiology of Livestock. 1st ed. R. J. Collier, ed. John Wiley \& Sons, Chichester, UK.

Stott, G. H., F. Wiersma, B. E. Menefee, and F. R. Radwanski. 1976. Influence of environment on passive immunity in calves. J. Dairy Sci. 59:1306-1311.

Stull, C. L., L. L. Messam, C. A. Collar, N. G. Peterson, A. R. Castillo, B. A. Reed, K. L. Andersen, and W. R. VerBoort. 2008. Precipitation and temperature effects on mortality and lactation parameters of dairy cattle in California. J. Dairy Sci. 91:4579-4591.

Sullivan, M. L., A. J. Cawdell-Smith, T. L. Mader, and J. B. Gaughan. 2011. Effect of shade area on performance and welfare of short-fed feedlot cattle. J. Anim. Sci. 89:2911-2925.

Svensson, C., and P. Liberg. 2006. The effect of group size on health and growth rate of Swedish dairy calves housed in pens with automatic milk-feeders. Prev. Vet. Med. 73:43-53.

Svensson, C., K. Lundborg, U. Emanuelson, and S.-O. Olsson. 2003. Morbidity in Swedish dairy calves from birth to 90 days of age and individual calf-level risk factors for infectious diseases. Prev. Vet. Med. 58:179-197.

Syrstad, O. 1989. Dairy cattle cross-breeding in the tropics: Performance of secondary cross-bred populations. Livest. Prod. Sci. 23:97-106.

Tao, S., and G. E. Dahl. 2013. Invited review: Heat stress effects during late gestation on dry cows and their calves. J. Dairy Sci. 96:40794093.

Theurer, M. E., D. E. Anderson, B. J. White, M. D. Miesner, and R. L. Larson. 2014. Effects of weather variables on thermoregulation of calves during periods of extreme heat. Am. J. Vet. Res. $75: 296-300$.

Turnbull, J. E. 1980. Housing and environment for dairy calves. Can Vet. J. 21:85.

Turnpenny, J. R., A. J. McArthur, J. A. Clark, and C. M. Wathes. 2000. Thermal balance of livestock: 1. A parsimonious model. Agric. For. Meteorol. 101:15-27.

Tzou, G. G., D. O. Everson, R. C. Bull, and D. P. Olson. 1991. Classification of beef calves as protein-deficient or thermally stressed by discriminant analysis of blood constituents. J. Anim. Sci. 69:864873.
Van Iaer, E., C. P. H. Moons, B. Sonck, and F. A. M. Tuyttens. 2014 Importance of outdoor shelter for cattle in temperate climates. Livest. Sci. 159:87-101.

Vasseur, E., F. Borderas, R. Cue, D. Lefebvre, D. Pellerin, J. Rushen, K. Wade, and A. de Passillé. 2010. A survey of dairy calf management practices in Canada that affect animal welfare. J. Dairy Sci. 93:1307-1315

Vermorel, M., J. Vernet, C. Dardillat, Saido, C. Demigne, and M.J. Davicco. 1989a. Energy metabolism and thermoregulation in the newborn calf; effect of calving conditions. Can. J. Anim. Sci. 69:113-122.

Vermorel, M., J. Vernet, C. Dardillat, Saido, C. Demigne, and M.-J. Davicco. 1989b. Energy metabolism and thermoregulation in the newborn calf; variations during the first day of life and differences between breeds. Can. J. Anim. Sci. 69:113-122.

Virtala, A.-M. K., G. D. Mechor, Y. T. Gröhn, and H. N. Erb. 1996 The effect of calfhood diseases on growth of female dairy calves during the first 3 months of life in New York State. J. Dairy Sci. 79:1040-1049.

von Keyserlingk, M. A. G., J. Rushen, A. M. de Passillé, and D. M. Weary. 2009. Invited review: The welfare of dairy cattle - Key concepts and the role of science. J. Dairy Sci. 92:4101-4111.

Wagner-Storch, A. M., and R. W. Palmer. 2002. Day and night seasonal temperature differences for a naturally ventilated freestall barn with different stocking densities. J. Dairy Sci. 85:3534-3538.

Walker, W. L., W. B. Epperson, T. E. Wittum, L. K. Lord, P. J Rajala-Schultz, and J. Lakritz. 2012. Characteristics of dairy calf ranches: Morbidity, mortality, antibiotic use practices, and biosecurity and biocontainment practices. J. Dairy Sci. 95:2204-2214.

Waltner-Toews, D., S. W. Martin, and A. H. Meek. 1986. Dairy calf management, morbidity and mortality in Ontario Holstein herds. III. Association of management with morbidity. Prev. Vet. Med. 4:137-158

Wathes, C. M., C. D. R. Jones, and A. J. F. Webster. 1983. Ventilation, air hygiene and animal health. Vet. Rec. 113:554-559.

Webster, A. J. F. 1974. Heat loss from cattle with particular emphasis on the effects of cold. Pages 205-232 in Heat Loss from Animals and Man. 1st ed. J. L. Monteith and L. E. Mount, ed. Butterworths, London, UK.

Webster, A. J. F., J. Chlumecky, and B. A. Young. 1970. Effects of cold environments on the energy exchanges of young beef cattle. Can. J. Anim. Sci. 50:89-100.

Werner, J. 2010. System properties, feedback control and effector coordination of human temperature regulation. Eur. J. Appl. Physiol 109:13-25.

West, J. W. 2003. Effects of heat-stress on production in dairy cattle. J. Dairy Sci. 86:2131-2144.

Wójcik, J., R. Pilarczyk, A. Bilska, O. Weiher, and P. Sanftleben. 2012. Performance and health of group-housed calves kept in igloo calf hutches and calf barn. Pak. Vet. J. 33:175-178.

Young, B. A. 1981. Cold stress as it affects animal production. J. Anim. Sci. 52:154-163.

Young, B. A. 1983. Ruminant cold stress: Effect on production. J. Anim. Sci. 57:1601-1607. 